\title{
Distribution of Nitrifying Activity in the Seine River (France) from
}

\section{Paris to the Estuary}

\author{
NATACHA BRION ${ }^{1}$ \\ Groupe de Microbiologie des Milieux Aquatiques \\ Université Libre de Bruxelles \\ CP 221, Campus Plaine \\ Boulevard du Triomphe \\ 1050 Brussels, Belgium \\ Gilles BiLlen \\ Unité Mixte de Recherche Centre National de Recherche Scientifique Sisyphe \\ Université Paris 6 \\ Place Jussieu 4 \\ 75005 Paris, France \\ LOÏC GuÉZENNEC \\ Agence de l'Eau Seine Normandie \\ 51 me Salvador-Allende \\ 92027 Nanterre \\ Cedex, France \\ ANDRÉ FICHT \\ Service de la Navigation de la Seine \\ Cellule de lutte contre la polution \\ 66 Av. J. Chastellain \\ Ile Lacroix \\ 76000 Rouen, France
}

\begin{abstract}
The distribution of nitrification has been measured with the $\mathrm{H}^{14} \mathrm{CO}_{3}^{-}$incorporation method in the Seine River and its estuary during summer conditions. The Seine River below Paris receives large amounts of ammonium through wastewater discharge. In the river itself, this ammonium is only slowly nitrified, while in the estuary nitrification is rapid and complete. We show that this contrasting behavior is related to the different hydrosedimentary conditions of the two systems, as nitrifying bacteria are associated with suspended particles. In the river, particles and their attached bacteria either rapidly settle or have a sestonic behavior. Because of the short residence times of the water masses, the slow growing nitrifying population has no time to develop sufficiently to nitrify the available ammonium. The estuary is characterized by strong tidal dynamics. Particles settle and are resuspended continuously with the strong current inversions of ebb and flood. As a result of these dynamics, particles and their attached nitrifying bacteria experience longer residence times in a temporary suspended state than the water masses themselves, providing to slow growing nitrifying bacteria the opportunity to develop a large population capable of nitrifying all the available ammonium.
\end{abstract}

\section{Introduction}

In river systems, nitrification plays an important role in the nitrogen cycle but is also an important oxygen consuming process (e.g., Déri 1991). This is particularly true in wastewater contaminated riv-

\footnotetext{
${ }^{1}$ Corresponding author: current address: Vrije Universiteit Brussels, Faculteit Wetenschappen Analytische Chemie (WE ANCH), Pleinlaan 2, 1050 Brussels, Belgium; tele: 322/629 32 64; fax: 322/629 32 74; e-mail: nnbrion@vub.ac.be.
}

ers which receive directly or indirectly (through organic $\mathrm{N}$ mineralization) large amounts of ammonium favorable to the development of nitrification. In rivers, ammonium can be nitrified in the sediments and the water column, the relative significance of each being a function of the surface to volume $(\mathrm{S}: \mathrm{V})$ ratio of the river. In small rivers, ammonium is mostly nitrified by the benthic community (Cooper 1984). In larger rivers, because of the smaller $\mathrm{S}: \mathrm{V}$ ratio, benthic nitrification is insig- 
nificant and most of the oxidation of ammonium takes place in the water column (Billen 1975; Lipschultz et al. 1986; Chestérikoff et al. 1992; Berounsky and Nixon 1993).

The capacity of large streams to oxidize ammonium is strongly related to their capacity to maintain a large nitrifying population. Nitrifying bacteria are characterized by their very slow growth (maximum growth rate between 0.035 and 0.06 $\mathbf{h}^{-1}$, Gould and Lees 1960; Skinner and Walker 1961; Boon and Laudelout 1962; Helder and De Vries 1983; Brion and Billen 1998); they need long residence times to develop a significant biomass in the water column. It is commonly known that nitrifying bacteria have the capacity to attach to surfaces and this capacity is largely used in wastewater treatment technologies (Bovendeur et al. 1990). In aquatic systems, this can represent an advantage for those slow growing organisms by allowing them to stay longer at one site without being flushed out. Déri (1991) showed that in the Hungarian stretch of the River Danube, very rapid and frequent discharge variations led to alternate resuspension and settling periods, with the periods of maximum turbidity coinciding with the maximum nitrifying activity. In the same way, Admiraal and Bottermans (1989) showed that in the three branches of the Rhine estuary, the most turbulent and turbid stretch characterized by the most intense shipping was also the site of the most intense nitrification. Finally, Owens (1986) compared the functioning of the nitrifying Tamar estuary to a fluidized bed reactor, with the tidal movements maintaining attached bacteria in suspension.

For the Seine River below Paris, Chestérikoff et al. (1992) showed that the very large amounts of ammonium brought by the wastewater treatment plant of Paris (10 million inhabitants) were only slowly nitrified even in summer low water conditions because of the slow growth of nitrifying organisms. The nitrifying population requires several days (more than the residence time) to reach densities able to induce a measurable ammonium depletion in the river. In contrast, when entering the estuary, separated from the upstream section of the river by a navigation dam, ammonium is almost totally nitrified under favorable summer temperature conditions.

This paper shows that the contrasting expression of nitrification in the riverine and estuarine parts of the Seine is related to the different hydrological conditions prevailing in those two systems. While the hydrodynamic behavior of the river is characterized by the unidirectional river discharge, the estuary is also influenced by strong tidal dynamics. We investigated the interactions between nitrifying bacteria and suspended particles, and their implications on the nitrifying population dynamics.

\section{SITE DESCRIPTION}

The study area corresponds to the downstream part of the Seine River and its estuary (Fig. 1a). It extends over $355 \mathrm{~km}$ from Paris to Honfleur. The sampling sites along the stream are referenced as distance $(\mathrm{km})$ from the Marie bridge, located in the center of the city of Paris, and increasing downstream according to a convention of the Service de la Navigation de la Seine (SNS). The Seine River below Paris is a large regulated 7th order river according to the Strahler (1957) classification (the confluence of two rivers of order $\mathrm{n}$ gives a river of order $\mathrm{n}+1$, with $\mathrm{n} \geq 1$ ). A few kilometers downstream from Paris, the river receives the effluents of the wastewater treatment plant of Achères, treating the sewage of the 10 million inhabitants of the Parisian metropolitan areas. The confluence with River Oise comes immediately after this wastewater discharge. The mean discharge of the river is 420 $\mathrm{m}^{3} \mathrm{~s}^{-1}$. The river runs over $100 \mathrm{~km}$ to Poses, the beginning of the estuary, where a navigation dam prevents the tidal wave from penetrating farther upstream. The estuary extends over $150 \mathrm{~km}$ and is strongly channelled, with a width of a few hundred meters and a mean depth of about $4 \mathrm{~m}$ from Poses to Rouen, and $10 \mathrm{~m}$ downstream from Rouen. It has a mean residence time of about $8 \mathrm{~d}$. The macrotidal hydrodynamic behavior of the estuary is controlled by the combination of river discharge and tide, which can successively join or be opposed during ebb and flood. During a lunar cycle, the tidal amplitude varies with the alternation of neap and spring tides. The maximum tide amplitude at the mouth of the estuary is $7.5 \mathrm{~m}$, and the tidal wave is gradually dampened and distorted when entering the estuary, reaching only $30 \mathrm{~cm}$ in the front of the Poses dam. The intrusion of salinity never extends beyond Caudebec, $40 \mathrm{~km}$ from the river mouth in the Seine Bay. In the largest part of the estuary, there is no dilution of freshwater with marine waters.

\section{Methods \\ Physical, Chemical, AND Biological MeAsurements}

Ammonium $\left(\mathrm{NH}_{4}\right)$, nitrate $\left(\mathrm{NO}_{3}\right)$, and nitrite $\left(\mathrm{NO}_{2}\right)$ analyses were carried out on $0.45-\mu \mathrm{m}$ filtered water, directly after collection. $\mathrm{NH}_{4}$ was measured with the indophenol blue method according to Slawyk and McIsaac (1972). $\mathrm{NO}_{3}$ was measured after cadmium reduction in $\mathrm{NO}_{2}$. $\mathrm{NO}_{2}$ was measured with the sulphanilamide method according to Jones (1984). River discharges (Q) were given daily at the Poses dam $(198 \mathrm{~km})$ by the SNS. Ox- 


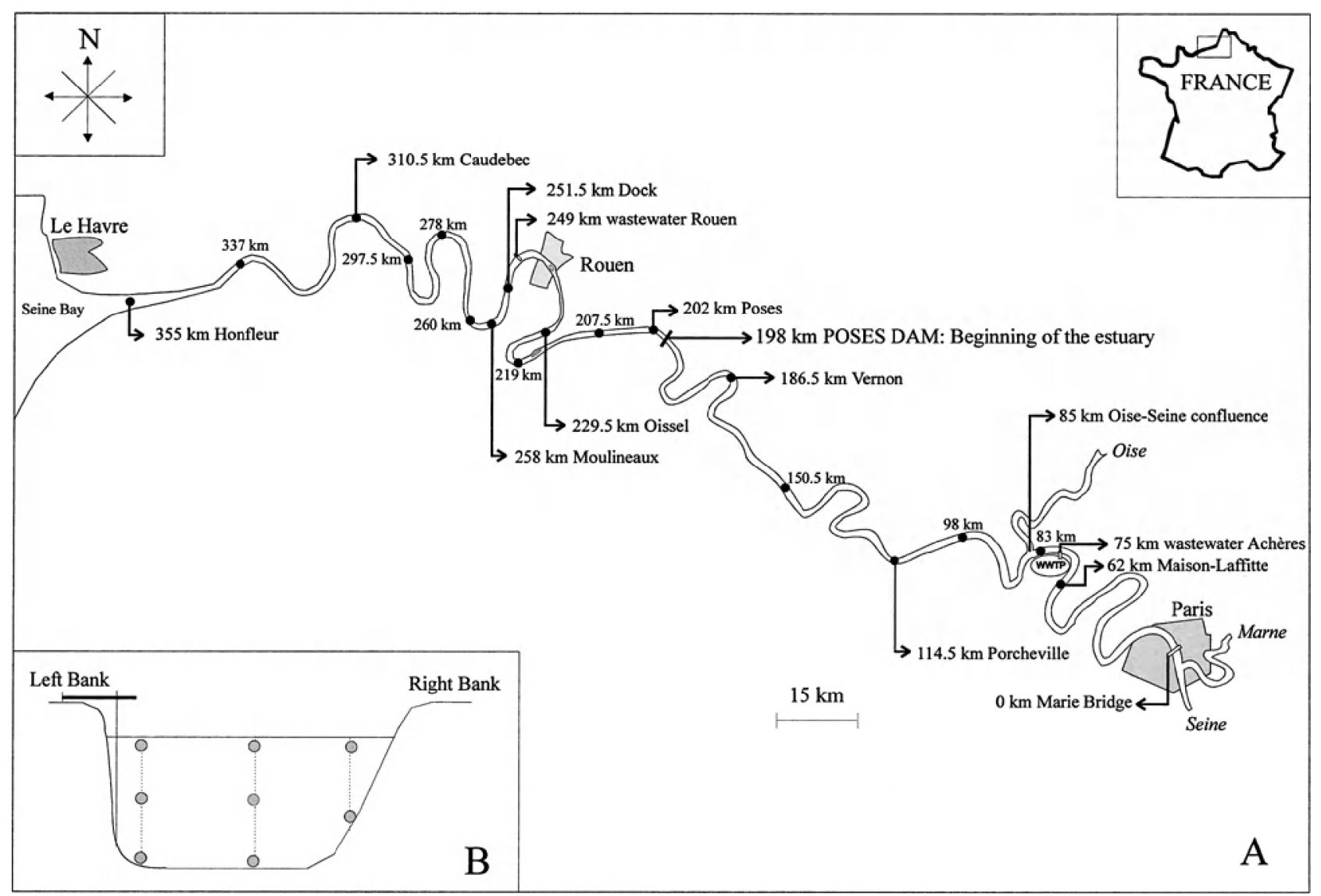

Fig. 1. A) Schematic representation of the Seine River below Paris. Black circles are the sampling stations; the name of the stations and their position (distance from the Marie Bridge in Paris) are pointed out with arrows. WWTP: Wastewater treatment plant of Achères $(75 \mathrm{~km})$. B) Schematic representation of the cross section of the estuary at station Moulineaux $(258 \mathrm{~km})$. Circles represent the sampling sites.

TABLE 1. Hydrologic and climatic characteristics of the 10 cruises and linear regression of potential nitrifying activity (pNA, $\mu$ mol $\mathrm{l}^{-1} \mathrm{~h}^{-1}$ ) versus suspended matter $\left(\mathrm{SM}, \mathrm{mg} \mathrm{l}^{-1}\right.$ ) concentrations for 7 tidal profiles. $\mathrm{Q}=$ river discharge $\left(\mathrm{m}^{3} \mathrm{~s}^{-1}\right)$. tc $=$ tide coefficient (relative tidal range in $\%$ of the mean spring equinox tidal range, $6.7 \mathrm{~m}$, given for the Brest Harbour on the French Atlantic coast). $\mathrm{T}=$ temperature $\left({ }^{\circ} \mathrm{C}\right)$. A and $\mathrm{B}$ are coefficients of the linear regression pNA $=\mathrm{A} \times \mathrm{SM}+\mathrm{B}$. $\mathrm{R}$ is the regression coefficient. $\mathrm{p}$ is the probability that the regression coefficient $\mathrm{R}$ is zero. $\mathrm{n}=$ number of observations. $\mathrm{ns}=$ no significant correlation between $\mathrm{pNA}$ and $\mathrm{SM}(\mathrm{p}>0.05)$.

\begin{tabular}{|c|c|c|c|c|c|c|c|c|}
\hline Date & Q & tc & I & A & B & $\mathrm{R}$ & $\mathrm{p}$ & $\mathrm{n}$ \\
\hline \multicolumn{9}{|c|}{ Longitudinal Profiles } \\
\hline July 3-4, 1995 & 290 & 68 & 22 & - & - & - & - & - \\
\hline September $12-13,1995$ & 296 & 89 & 18 & - & - & - & - & - \\
\hline July 3-4, 1996 & 141 & 106 & 19 & - & - & - & - & - \\
\hline \multicolumn{9}{|c|}{ Tidal Profiles } \\
\hline July 21, 1993 & 205 & 101 & 20 & 0.037 & -0.34 & 0.82 & 0.003 & 10 \\
\hline November 4,1993 & 450 & 68 & 9 & $-0.003^{\mathrm{ns}}$ & $0.21^{\mathrm{ns}}$ & -0.13 & 0.71 & 10 \\
\hline March 17, 1994 & 680 & 71 & 10 & $0.0032^{\mathrm{ns}}$ & $-0.04^{\mathrm{ns}}$ & 0.45 & 0.36 & 6 \\
\hline May 20, 1994 & 500 & 55 & 16.5 & 0.0055 & 0.016 & 0.89 & 0.003 & 8 \\
\hline June 15,1994 & 500 & 67 & 18 & 0.0075 & -0.070 & 0.84 & 0.035 & 6 \\
\hline July 17,1994 & 150 & 71 & 22.5 & 0.043 & -1.19 & 0.85 & 0.007 & 8 \\
\hline September 27, 1996 & 140 & 108 & 16 & 0.015 & 0.11 & 0.82 & $<0.001$ & 36 \\
\hline
\end{tabular}


(A)
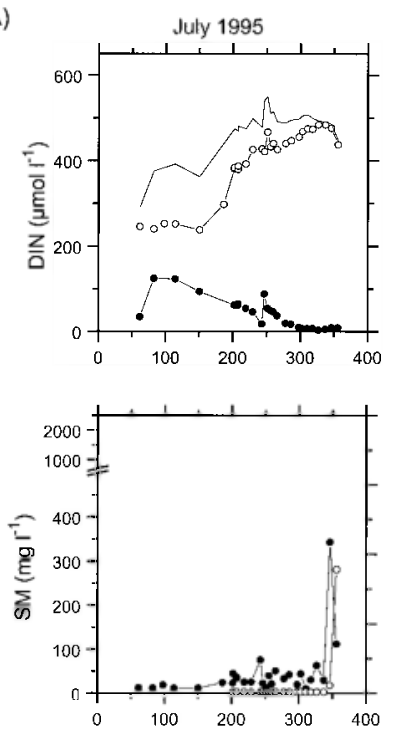

(B)
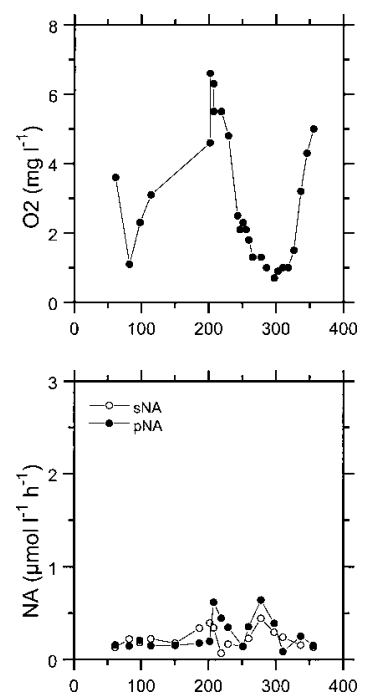
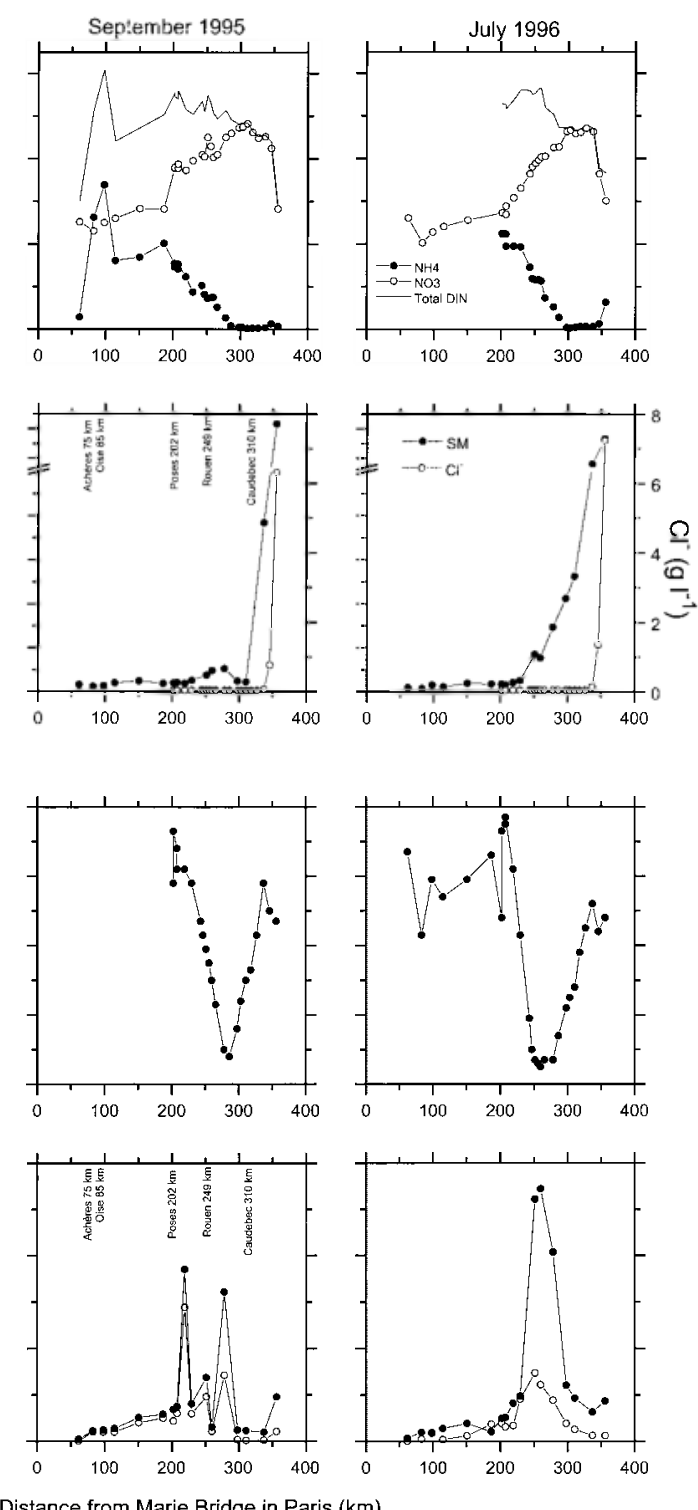

Fig. 2. Longitudinal variations from Maison-Laffitte $(62 \mathrm{~km})$ to Honfleur $(355 \mathrm{~km})$ of A) ammonium $\left(\mathrm{NH}_{4}\right)$, nitrate $\left(\mathrm{NO}_{3}\right)$, total dissolved inorganic nitrogen (DIN), suspended matter (SM), chlorinity $(\mathrm{Cl})$; B) oxygen $\left(\mathrm{O}_{2}\right)$ concentrations and potential nitrifying activity (pNA) and simulated in situ nitrifying activity (sNA) for July 1995, September 1995, and July 1996. For station locations, see Fig. 1a.

ygen concentrations $\left(\mathrm{O}_{2}\right)$ were determined using a specific probe (OXY 96, WTW). Suspended matter concentrations (SM) were determined by filtering 100 to $300 \mathrm{ml}$ of water immediately after collection through a $0.45-\mu \mathrm{m}$ dried pre-weighed glass fibre filter (GFF, Whatmann). The filter was then put in a drying oven at $80^{\circ} \mathrm{C}$ for $4 \mathrm{~h}$, and weighed again. Suspended matter concentration was determined by the difference.

Nitrifying activities were measured on water samples immediately after collection with the $\mathrm{H}^{14} \mathrm{CO}_{3}{ }^{-}$ incorporation method according to Brion and Bil- len (1998). The method involves measuring the difference in dark $\mathrm{H}^{14} \mathrm{CO}_{3}{ }^{-}$incorporation rates between a control sample and a sample treated with specific inhibitors of chemoautotrophic nitrification: N-serve ( = 2-chloro-6-trichloromethyl pyridine $=$ Nitrapyrine) at a final concentration of 5 $\mathrm{mg} \mathrm{l}^{-1}$ and chlorate at a final concentration of 10 mmol $1^{-1}$. The carbon incorporation rates were converted into ammonium oxidation to nitrate rates by using a conversion factor of 0.11 ( $\mu \mathrm{mol}$ oxidized $\mathrm{N}) \times(\mu \mathrm{mol} \text { incorporated } \mathrm{C})^{-1}$ which was considered to be constant in the standardized in- 

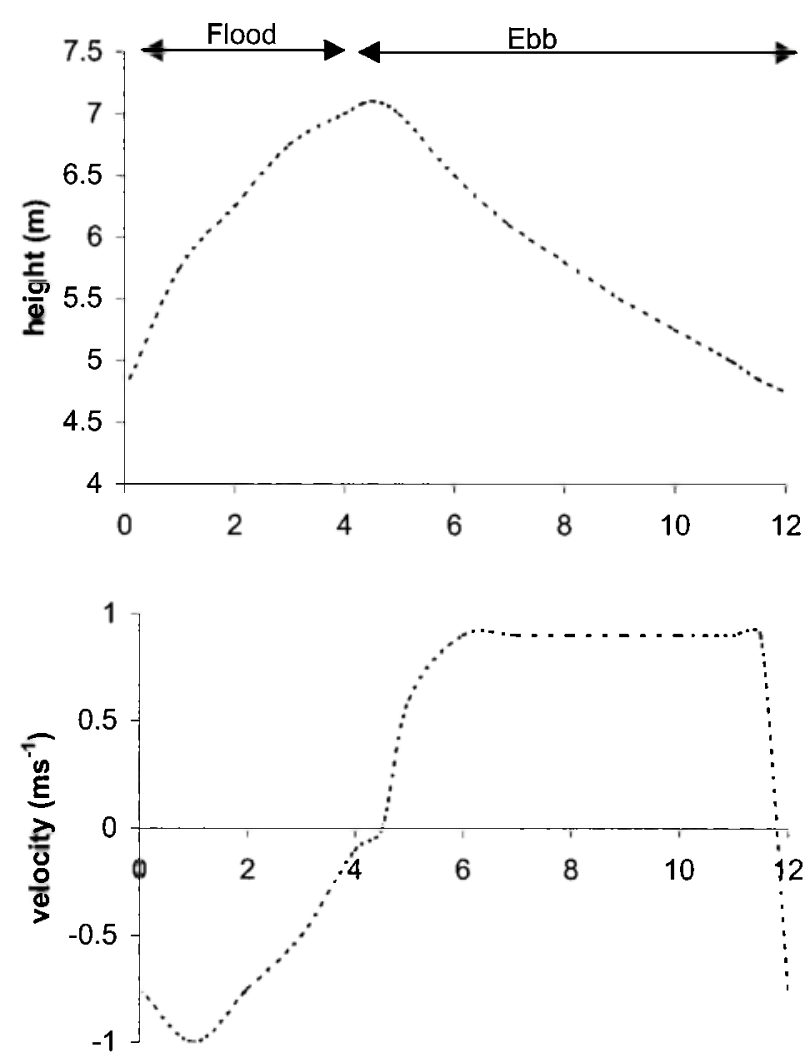

Time after low tide (h)

Fig. 3. Current velocity and water column height during a typical tidal cycle measured at Moulineaux $(258 \mathrm{~km})$. cubation conditions (Brion and Billen 1998). Potential nitrifying activities ( $\mathrm{pNA}$ ) were measured at saturating ammonium (2 $\mathrm{mmol} \mathrm{l}^{-1}$ ) and oxygen (shaking of the sample on a rotary table) concentrations and at a constant temperature of $20^{\circ} \mathrm{C}$. Under these conditions, nitrifying activity is directly related to nitrifying biomass (Belser and Mays 1982). Simulated in situ nitrifying activities (sNA) were measured by incubating the samples in Winkler bottles without a headspace and at in situ temperature.

\section{SAMPLING AND CRUISES \\ Longitudinal Profiles}

Longitudinal profiles of nitrifying activity were established during three cruises conducted under low river discharge conditions in July and September 1995 and in July 1996. Each sampling cruise ran over $2 \mathrm{~d}$. On the first day, upstream stations between 62 and $230 \mathrm{~km}$ were sampled from bridges during the ebb. On the second day, downstream stations between 250 and $355 \mathrm{~km}$ were sampled from a small ship of the SNS during the flood except for the most downstream stations at 355 and $337 \mathrm{~km}$, which were sampled at the end of the ebb. All samples were taken in the middle of the river in the first $3 \mathrm{~m}$ of the water column, either with a bucket (upstream samples) or with a peristaltic pump (downstream samples). The river discharge, water temperature, and tide coefficient of each cruise are given in Table 1.

\section{Tidal Profiles}

The tidal variability of potential nitrifying activities and suspended matter concentrations were as-
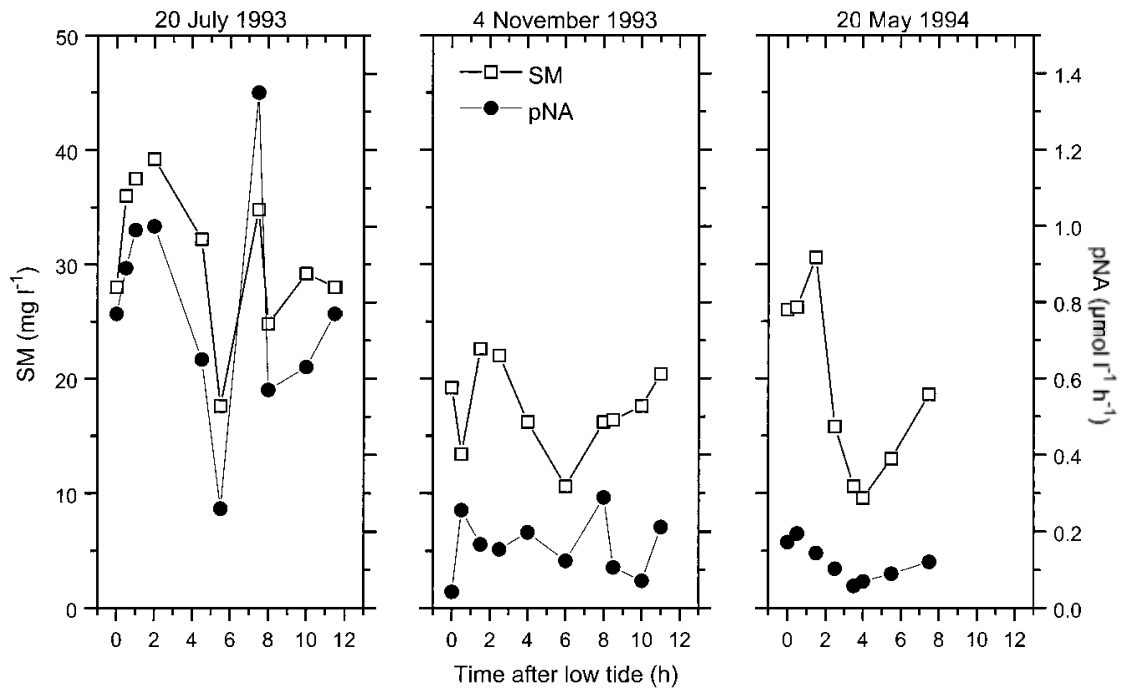

Fig. 4. Typical suspended matter concentration (SM) and potential nitrifying activity (pNA) variations on surface samples at station Moulineaux $(258 \mathrm{~km})$ during 3 tidal cycles. 


\section{(A) SM (mg l-1)}

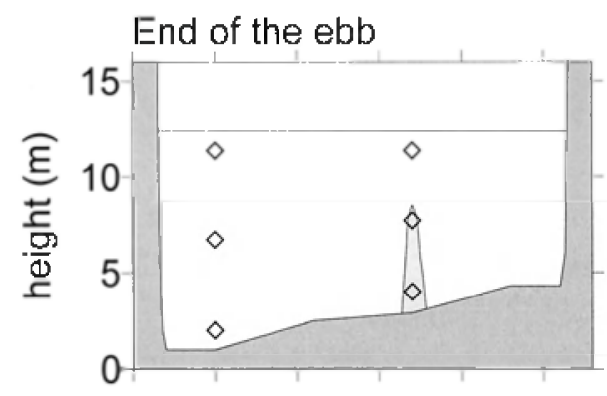

Beginning of the flood

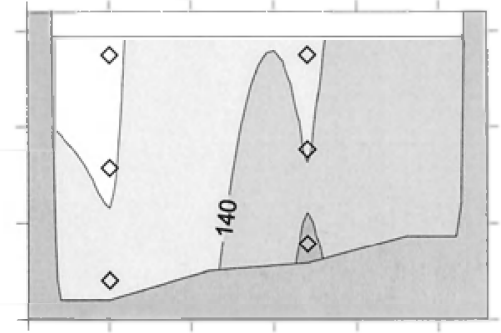

High tide
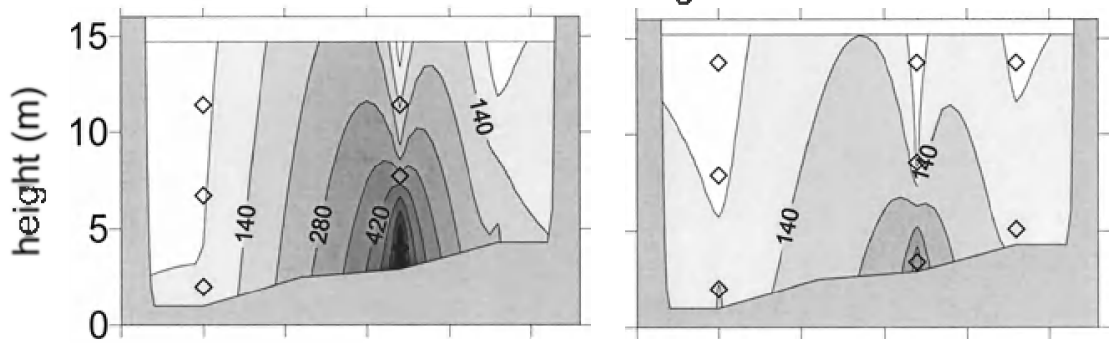

Middle of the ebb

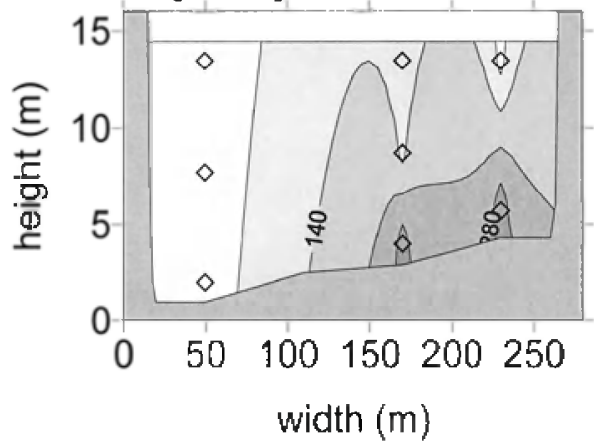

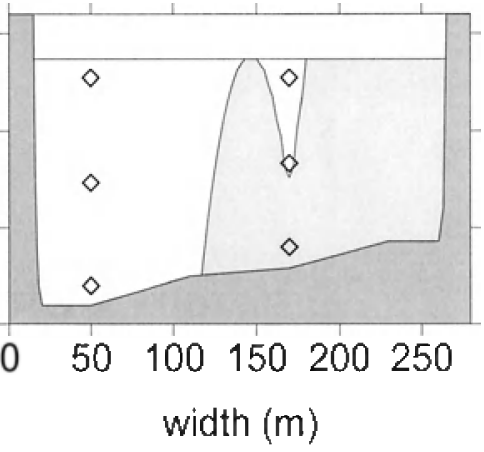

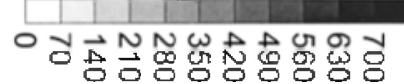

Fig. 5. Tidal variation of (A) suspended matter concentration (SM) and (B) potential nitrifying activity (pNA) on a cross-section at station Moulineaux (258 km). Diamonds represent the measurements. Concentrations were extrapolated from the measurements over the entire river section using the Kriging method (Surfer version 4 Reference manual) of computer program SURFER (Golden Software).

sessed for seven cruises conducted at a station located around the middle of the estuary: Moulineaux, $258 \mathrm{~km}$ (Fig. 1a). Cruises followed $12 \mathrm{~h}$ tidal cycles and covered different seasonal and tidal situations. Water temperature, river discharge, and tide coefficients of each cruise are summarized in Table 1. Between July 1993 and July 1994 (six cruises), samples were taken of the surface water with a bucket from a small pier on the left bank (Fig. 1b). On September 27, 1996, samples were taken from a ship (Côte d'Aquitaine, C.N.R.S.) with 5-1 Niskin's bottles at three depths (bottom, center, and surface of the water column) and at three stations across the river (left bank, middle, and right bank) (Fig. 1b).

\section{SEDIMENTATION OF PNA AND SM}

To illustrate the inter-relationship between suspended particles and nitrifying bacteria in estuarine waters, the settlement of $\mathrm{pNA}$ and $\mathrm{SM}$ were 
(B) pNA ( $\mu$ mol l-1 h-1)
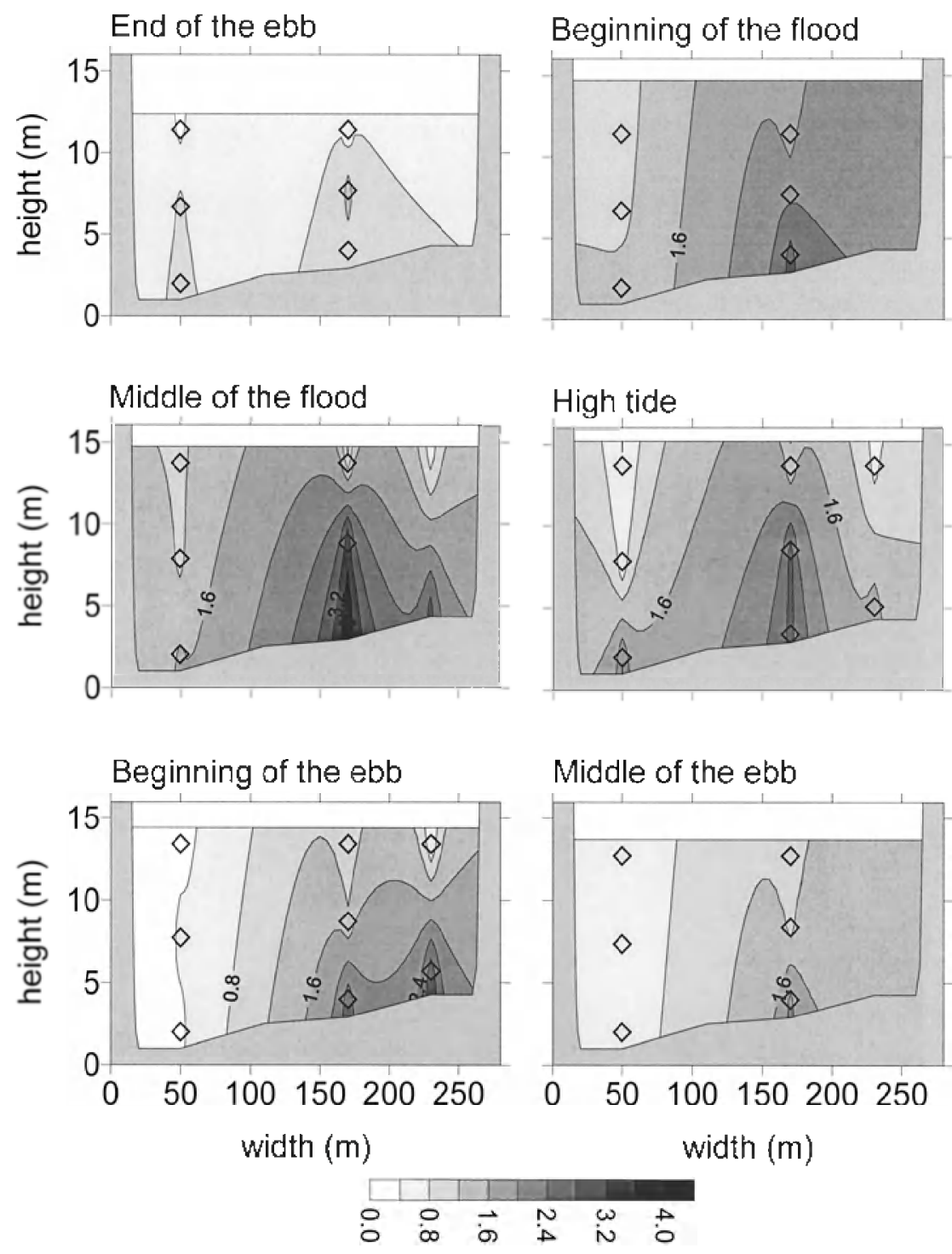

Fig. 5. Continued

followed in parallel over time in a mesocosm experiment. At station Moulineaux $(258 \mathrm{~km})$, on July 23, 1997, seven plastic cylinder tubes were gently immersed side to side in a vertical position under the water surface, closed at their bottom end, and carefully brought up to the river bank where they were placed with minimal disturbance in an incubator at in situ temperature. Immediately, the upper $20 \mathrm{~cm}$ of the first cylinder were siphoned and homogenised. The others were allowed to settle for $5,15,30,60,120$, and 240 minutes respectively before being siphoned and homogenised. pNA and SM were determined on each collected sample.

\section{Results}

Longitudinal Profiles

The 3 sets of longitudinal profiles cover summer situations; a situation with a river discharge of about $300 \mathrm{~m}^{3} \mathrm{~s}^{-1}$ and a mean water temperatures of $18^{\circ} \mathrm{C}$ (September 1995) and $22^{\circ} \mathrm{C}$ (July 1995), and a situation with a lower river discharge (141 $\mathrm{m}^{3} \mathrm{~s}^{-1}$ ) and a mean water temperature of $19.5^{\circ} \mathrm{C}$ (July 1996) (Table 1). Suspended matter concen- 
trations are rather low and constant in the river (10 to $20 \mathrm{mg}^{-1}$ ), while in the upper part of the estuary, they are more variable and generally higher (40 to $50 \mathrm{mg} \mathrm{l}^{-1}$ ) (Fig. 2a). The downstream part of the estuary is characterized by the presence of a turbidity maximum (up to $2 \mathrm{~g} \mathrm{l}^{-1}$ of SM) as previously described by Avoine et al. (1981). This turbidity maximum is particularly evident in September 1995 and July 1996.

Ammonium concentrations vary between 0 and $350 \mathrm{mmol} \mathrm{l}^{-1}$ (Fig. 2a). The discharge of the Achères wastewater treatment plant at $75 \mathrm{~km}$ causes a sudden increase. Between 75 and $202 \mathrm{~km}$, concentration decreases in July 1995 while it increases in September 1995 after the dilution with the River Oise $(85 \mathrm{~km})$. From $202 \mathrm{~km}$ and downstream, in the estuary, ammonium concentrations decrease until they reach undetectable limits. Nitrate concentrations vary between 200 and $500 \mu \mathrm{mol} 1^{-1}$ and increase downstream (Fig. 2a). Total dissolved inorganic $\mathrm{N}$ concentrations $\left(\mathrm{DIN}=\mathrm{NH}_{4}+\mathrm{NO}_{2}+\right.$ $\mathrm{NO}_{3}$ ) vary between 300 and $650 \mu \mathrm{mol} \mathrm{l}^{-1}$ (Fig. 2a). An increase follows the discharge of wastewater at $75 \mathrm{~km}$ (Achères) and is immediately followed by a slight decrease at $85 \mathrm{~km}$ after the dilution with the River Oise. After this confluence, DIN increases downstream until $202 \mathrm{~km}$ (Poses), showing an influx coming from organic $\mathrm{N}$ mineralization. Between $202 \mathrm{~km}$ and $243 \mathrm{~km}$ (Rouen), DIN decreases slightly. Below $340 \mathrm{~km}$, the concentrations of all DIN species decrease suddenly due to dilution of river with seawater, as shown on the chlorinity profiles (Fig. 2a).

Oxygen concentrations decrease drastically just below the wastewater discharge of Achères $(75 \mathrm{~km})$ (Fig. 2b). Along its travel to the estuary, the water is then re-oxygenated by mixing with the River Oise $(85 \mathrm{~km})$ and by the waterfalls at several navigation dams. In the estuary, a second severe oxygen decrease is observed, with minimum values below $1 \mathrm{mg} \mathrm{l}^{-1}$ located around $300 \mathrm{~km}$ (Fig. 2b). Reoxygenation of the water masses only occurs at the most downstream stations by the mixing with marine waters.

Potential nitrifying activity varies from 0.05 to $2.75 \mu \mathrm{mol} \mathrm{l}^{-1} \mathrm{~h}^{-1}$ and profiles show a slow but regular increase of the nitrifying population from 75 (Achères) to $202 \mathrm{~km}$ (Poses) (Fig. 2b). In the estuary, pNA reaches very high values except in July 1995. Simulated in situ nitrifying activity measurements vary from 0 to $0.7 \mu \mathrm{mol} \mathrm{l}^{-1} \mathrm{~h}^{-1}$ with one value of $1.4 \mu \mathrm{nol} \mathbf{l}^{-1} \mathbf{h}^{-1}$ and show the same variation pattern as pNA, with almost no difference in the upstream part of the river before $202 \mathrm{~km}$. In the estuary, sNA values are lower than pNA values, especially in the downstream part of the estuary where low ammonium and oxygen concentration strongly limit the activity of the nitrifying population. Spatial patterns in sNA and pNA at the most downstream stations indicate the dilution of river with marine waters.

\section{Tidal Profiles}

A typical example of the tidal wave is shown in Fig. 3 (258 km, Moulineaux). It presents the succession of ebb and flood. During the $4 \mathrm{~h}$ of flood, the water column height increases rapidly to a maximum depending on the tide coefficient, and during the $8.5 \mathrm{~h}$ of ebb, it decreases slowly to a minimum. A very rapid flow inversion follows the ebb-flood succession and a much more progressive inversion follows the flood-ebb succession as seen on the velocity profiles (Fig. 3).

On surface samples, suspended matter concentrations (Fig. 4) measured at $258 \mathrm{~km}$ (Moulineaux) during several tidal cycles vary strongly during the tide. In general, concentrations are maximum in the first $2 \mathrm{~h}$ of the flood, following the current inversion $(t=0 \mathrm{~h})$ and then decrease during the flood and at high tide together with current velocity ( $2 \mathrm{~h}<t<\mathbf{4} \mathrm{h}$ ). Depending on the situation, SM starts to increase from the ebb current inversion $(t=4 \mathrm{~h})$ when current velocity increases, and reaches a smaller maximum 2 to $4 \mathrm{~h}$ later $(6 \mathrm{~h}<$ $t<8 \mathrm{~h}$ ). It is followed again by a decrease at the end of the ebb $(t>8 \mathrm{~h})$. Potential nitrifying activity profiles measured during the same tidal cycles show a similar variation pattern as suspended matter profiles (Fig. 4).

On a cross section, measurements of SM and pNA as determined in September 1996, show a strong spatial and tidal variability (Fig. 5a,b) with, again, a similar pattern for $\mathrm{pNA}$ variations as for SM. The six cross-section profiles correspond to 6 characteristic moments of the tidal cycle. At the end of the ebb, concentrations are relatively homogenous and low. At the beginning of the flood, concentrations increase, beginning from the bottom, as a result of the resuspension of particles following the current inversion. At the middle of the flood, a severe stratification results from the sinking of particles from surface waters and consequent accumulation of particles in the bottom layers. At high tide a strong sedimentation of SM and pNA in all parts of the water column follows the zero flow velocity. At the beginning of the ebb, SM concentrations increase beginning from the bottom as a result of the second current inversion, although to a lesser extent than for the flood inversion. Finally, at the middle of the ebb, concentrations become again relatively homogenous and low after sedimentation. There is also a strong asymmetry between the left bank and the right bank. This is related to the fact that the river at 


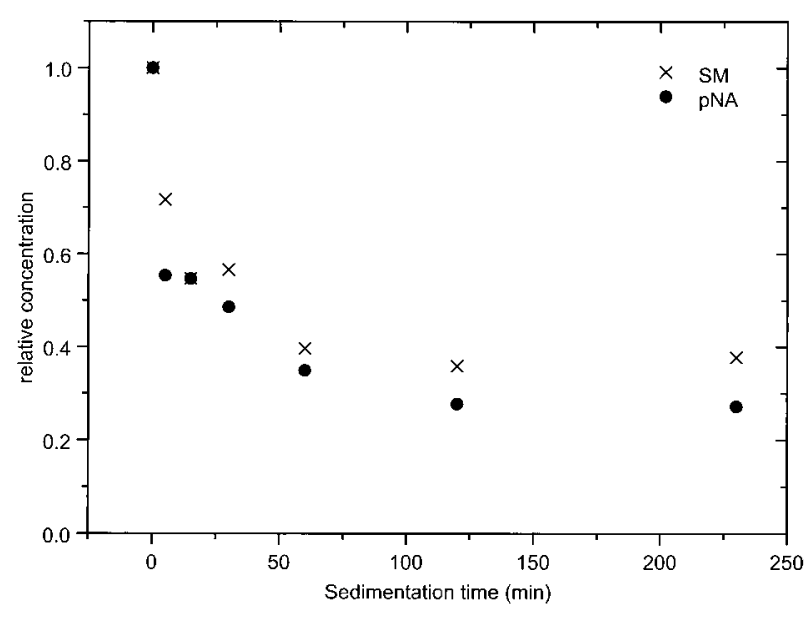

Fig. 6. Sedimentation kinetics of suspended matter (SM) and potential nitrifying activity (pNA).

this station $(258 \mathrm{~km}$ ) forms a loop (see Fig. 1a) with the left bank at the outer side. Particles accumulate more at the inner side of the loop (right bank), where current velocities during the ebb are more reduced.

\section{SEDIMENTATION OF PNA AND SM}

Results of this experiment (Fig. 6) show that SM and $\mathrm{pNA}$ have a very similar sedimentation profile with a $30-40 \%$ fraction non-decantable after 90 min.

\section{Discussion}

\section{Dissolved Inorganic Nitrogen Budget}

DIN fluxes in the river and estuary are presented in Fig. 7, in five successive stretches: $62-114 \mathrm{~km}$, where the Seine receives the wastewater discharge of Achères $(75 \mathrm{~km})$ and the River Oise $(85 \mathrm{~km})$; $114-186 \mathrm{~km}$, the last river stretch before the estuary; $186-230 \mathrm{~km}$, the upstream part of the estuary (with a little portion of the river as no samples were taken just at the end of the riverine section, $198 \mathrm{~km}) ; 230-251 \mathrm{~km}$, where the Seine receives the wastewater of the city of Rouen ( $249 \mathrm{~km})$; and $251-$ $310 \mathrm{~km}$, the downstream part of the estuary before the dilution with seawater. The incoming, outgoing, and internal N-fluxes in each stretch are calculated from the measured DIN, $\mathrm{NH}_{4}$, and $\mathrm{NO}_{3}$ at its upstream and downstream limits, and from the river discharge. Our calculations assume steadystate conditions and neglect phytoplanktonic N uptake as blooms in this season only occur in the upstream part of the river network (Garnier et al. 1995). Indeed, a recent review by Nedwell et al. (1999) came to the conclusion that phytoplanktonic N-uptake in estuaries receiving high loads of nitrogen is of limited importance as a sink for nitro- gen. In the long stretches without tributaries or wastewater inputs (stretches 2, 3, and 5), we consider that an increase of DIN only comes from an apparent mineralization of organic $\mathrm{N}$ in $\mathrm{NH}_{4}$ and that a decrease of DIN is only the result of an apparent $\mathrm{NO}_{3}$ denitrification. In these stretches, apparent nitrification is calculated by comparing the input and output concentrations of ammonium and taking into account the contribution of $\mathrm{NH}_{4}$ from apparent mineralization. In the short stretches with external inputs (stretches 1 and 4), we consider that a DIN increase is only the result of this point source taking into account the water discharge of the tributary and/or wastewater. By design, stretches submitted to external $\mathrm{N}$ inputs were defined as short as possible. In this way, biological process fluxes can be neglected because of the short residence times.

Calculated fluxes show that DIN dynamics in the river itself are dominated by the inputs of ammonium from wastewater discharge and from organic matter mineralization. Some nitrification also occurs but the major part $(63 \%$ to $90 \%)$ of the initial + brought + produced ammonium is delivered to the estuary without transformations. In the estuary, the dominant process affecting DIN dynamics is clearly nitrification with all the ammonium entering the system being oxidized. Some denitrification also occurs in the most downstream part of the system. Intense nitrification in estuaries of large rivers receiving important $\mathrm{NH}_{4}$ inputs is a general observation. Caspers (1981) identified a large zone of the freshwater section in the Elbe estuary where intense nitrification was correlated with a depletion of the oxygen concentration. In an earlier study, Billen (1975) also showed that, when oxygen concentrations were not limiting, nitrification was a major process in the Scheldt estuary. In the Delaware River estuary, Lipshultz et al. (1986, p. 701) also found that "quantitative assessment of nitrogen metabolism of a sewage impacted river clearly identified $\mathrm{NH}_{4}{ }^{+}$-oxidation as the major process affecting observed distributions of $\mathrm{NO}_{2}{ }^{-}, \mathrm{NO}_{3}{ }^{-}$and $\mathrm{NH}_{4}{ }^{+}$".

In accordance with the observed N-dynamics, the nitrifying activities measured in the Seine are relatively low in the river itself but much higher in the estuary. Our recorded sNA values $(0.07$ to 0.73 MunolN ${ }^{-1} \mathrm{~h}^{-1}$ ) are comparable to those found in summer in the Providence River estuary (Rhode Island, U.S.) (0.17 to $\left.0.46 \mu \operatorname{molN~} \mathrm{l}^{-1} \mathrm{~h}^{-1}\right)$ which also receives large amounts of treated wastewater (Berounsky and Nixon 1993).

\section{Consistency of DIN Budgets and Measured NitRIFICATION RATES}

We attempted to check the correspondence between our nitrifying activity measurements and the 


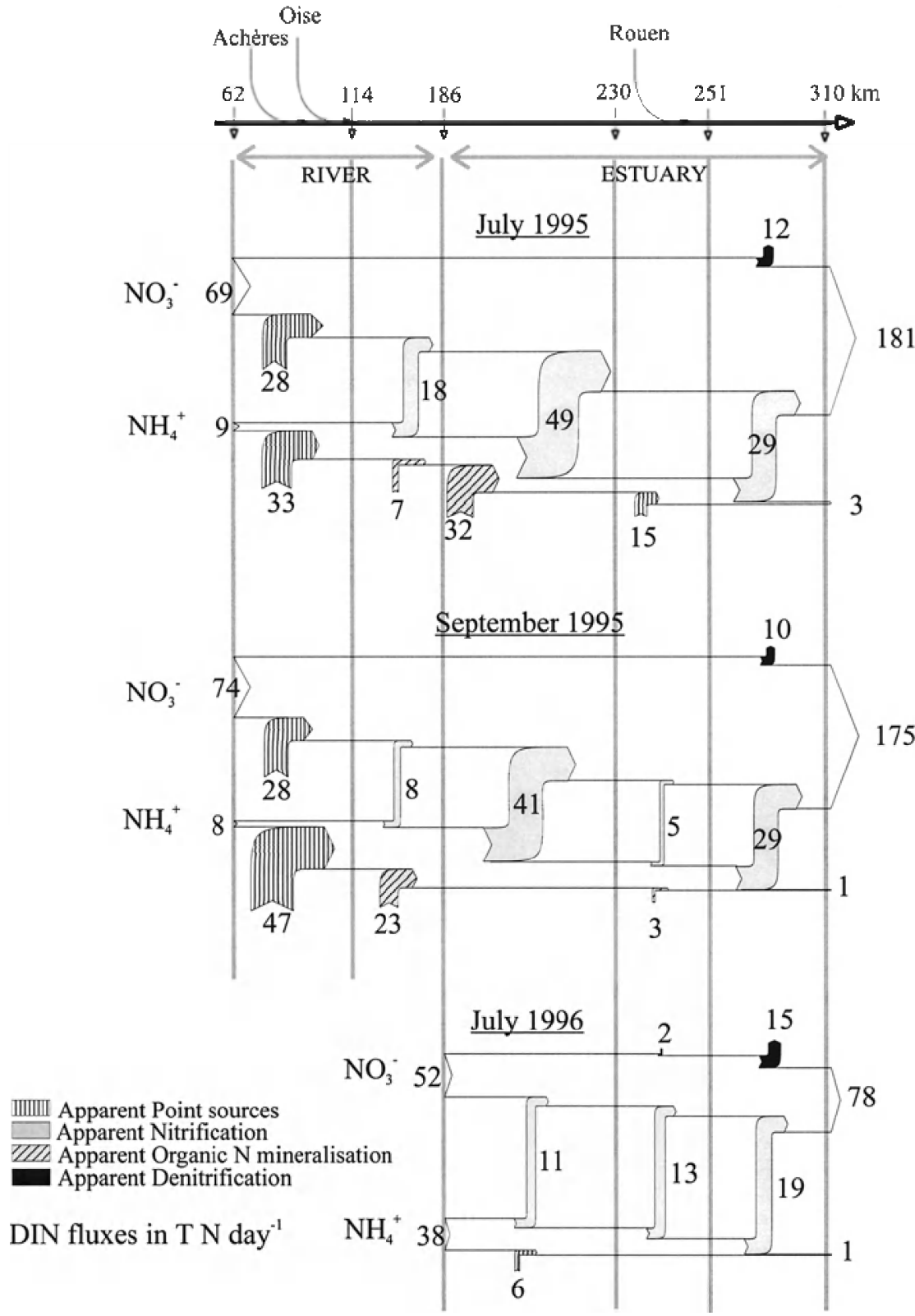

Fig. 7. Dissolved inorganic nitrogen (DIN) flows from $62 \mathrm{~km}$ (Maison-Laffitte) to $310 \mathrm{~km}$ (Caudebec, before the dilution with seawater) for the 3 longitudinal cruises. Flows are calculated as described in the text in five stretches of the river: $62-114 \mathrm{~km}, 114-$ $186 \mathrm{~km}, 186-230 \mathrm{~km}, 230-251 \mathrm{~km}$, and 251-310 km (see Fig. 1a).

above-described DIN budgets. Knowing the river's geometry (water sections given every $4 \mathrm{~km}$ for a given river discharge), it was possible to calculate the freshwater volume of the river and of the estuary. For the estuary the sections were integrated means taking into account the tidal variability of the water level over a neap-spring tide period. By multiplying those volumes with the corresponding nitrifying activities measured under in situ conditions, we obtain the $\mathrm{N}$-flux related to nitrification.
This flux derived from our sNA measurements is compared to the nitrification flux derived from our DIN budget (Fig. 7) in Table 2. In the river part of the Seine, fluxes derived from the sNA values are in good agreement with calculated fluxes although there is an underestimation of the measured nitrifying activities for July 1995 . This is probably linked to the sampling strategy that didn't follow the real water mass travel for the concentration measurements. Chestérikoff et al. (1992) who did 
TABLE 2. Comparison of nitrification fluxes derived from sNA measurements and from DIN budgets in the river and estuarine stretches of the Seine River. $\mathrm{V}=$ volume of freshwater in the stretch $\left(10^{8} \mathrm{~m}^{3}\right)$. NITmeas = nitrification flux derived from the sNA measurements calculated by multiplying the integrated average of measured in situ nitrifying activity in the stretch by $\mathrm{V}$ $\left(\mathrm{T}-\mathrm{N} \mathrm{d}^{-1}\right)$. NITcalc $=$ nitrification flux calculated from the DIN budget as in Fig. 7 (T-N d ${ }^{-1}$ ). June 1989-April 1990 data are from Chestérikoff et al. (1992).

\begin{tabular}{llcc}
\hline & & River & Estuary \\
\hline \multirow{2}{*}{ June 1989-April 1990 } & \multicolumn{1}{c}{ V } & 1.31 & 1.90 \\
& NITmeas & $0.3-0.7$ & - \\
July 1995 & NITcalc & $0.3-0.9$ & - \\
& NITmeas & 10 & 17 \\
September 1995 & NITcalc & 18 & 78 \\
July 1996 & NITmeas & 7 & 27 \\
& NITcalc & 8 & 75 \\
& NITmeas & 3 & 25 \\
& NITcalc & - & 43 \\
\hline
\end{tabular}

their experiments following the same water mass along its travel downstream from Paris to the Poses dam, found agreement between sNA values (measured with the same method) and DIN profiles. In the estuary fluxes derived from the sNA show a clear discrepancy with the calculated nitrification. It is obvious that there is an underestimation of the nitrifying activity measurements with regards to the observed ammonium decrease. To explain this discrepancy, we reconsidered our sampling strategy. Indeed, in the river, as well as in the estuary, samples were taken in the upper part of the water column. In the river, as the water column is known to be well mixed (Chestérikoff et al. 1992), surface samples are representative and sNA measurements do agree with measured DIN profiles. In the estuary we saw that there was a severe and variable vertical stratification of nitrifying activities, as well as of suspended matter. Consequently, surface samples taken at a given time of the tidal cycle are not likely to be representative of the water column.

To quantify this unrepresentativeness of our surface samples in the estuarine environment, we have to consider the close relationship between nitrifying bacteria and particulate material. We saw that they vary in the same way during tidal cycles and that they settle at similar rates, suggesting that most of the nitrifying bacteria are not free-living, but attached to the particles. Correlations between pNA and SM were established for each of our tidal profiles (Table 1) by linear regression. We see that a good relation generally exists as long as the range of the SM (and pNA) variation is large enough (Table 1). This is the case for the cruises of July 1993, May, June, and July 1994, and September 1996 which are characterized by a relatively low river discharge. In that case, the slope of the linear regressions gives an index of colonization of par- ticles by nitrifying bacteria. This pNA associated to particles vary seasonally from 5.5 to $43 \mu$ molN $g^{-1}$ $\mathbf{h}^{-1}$. Owens (1986) extensively discusses the same kind of correlation for the small Tamar estuary. He found a particle-associated pNA of 0.4 to 0.9 $\mu$ molN $\mathrm{g}^{-1} \mathbf{h}^{-1}$ which is less than our values but not surprising as we consider the small size of the Tamar River estuary (34 $\mathrm{m}^{3} \mathrm{~s}^{-1}$, Grabemann et al. 1997) in comparison with the Seine River estuary. In estuarine systems with frequent and sometimes rapid current changes, the result of the attachment of nitrifying bacteria to particles is that the distribution of sNA, like SM, is extremely heterogeneous within the water column, but also within the tidal cycle (Figs. 4 and 5). The representativeness of surface measurements in such a system is presented in Fig. 8 which shows the spatial variability of suspended material and pNA within a cross section of the estuary during the tidal cycle of September 27, 1996.

Except at the end of the ebb, surface measurements are always at the extreme lower limit of the distribution. For this situation we can calculate that surface measurements of SM and pNA are approximately 2 times lower than the corresponding cross section balanced means (ratio 1 to 5 according to the moment of the tidal cycle). Only at the end of the ebb, the water column is homogenous and surface samples are representative of the whole water column. So in this particular case, surface pNA measurements underestimate by a mean factor of two the actual cross section average. Although it was only determined at one station and for one tidal and seasonal situation, we see that applying this factor to our longitudinal sNA measurements in the estuary, results in a better agreement between nitrifying activity measurements and DIN budgets (Table 2).

\section{Consequence of the Coupled Suspended PARTICLES-NiTRIFICATION DyNAMICS}

A consequence of the coupled SM-pNA tidal dynamics is that the resuspension of particles during the flood's flow inversion, and their upstream transportation by the flood, followed by a significant sedimentation at high tide, could lead to a net accumulation of particles in some estuarine segments during low river discharge conditions. The seasonal variations of SM in the estuary (station Moulineaux, $258 \mathrm{~km}$ ) in comparison with the seasonal variations of SM in the river (Poses dam, $198 \mathrm{~km}$ ) illustrate this point (Fig. 9). Seasonal variations of SM at the estuarine station $(258 \mathrm{~km})$ show maximum concentrations when river discharge is minimum. The opposite pattern is observed at the riverine station $(198 \mathrm{~km})$ where maximum concentrations usually coincide with maxi- 

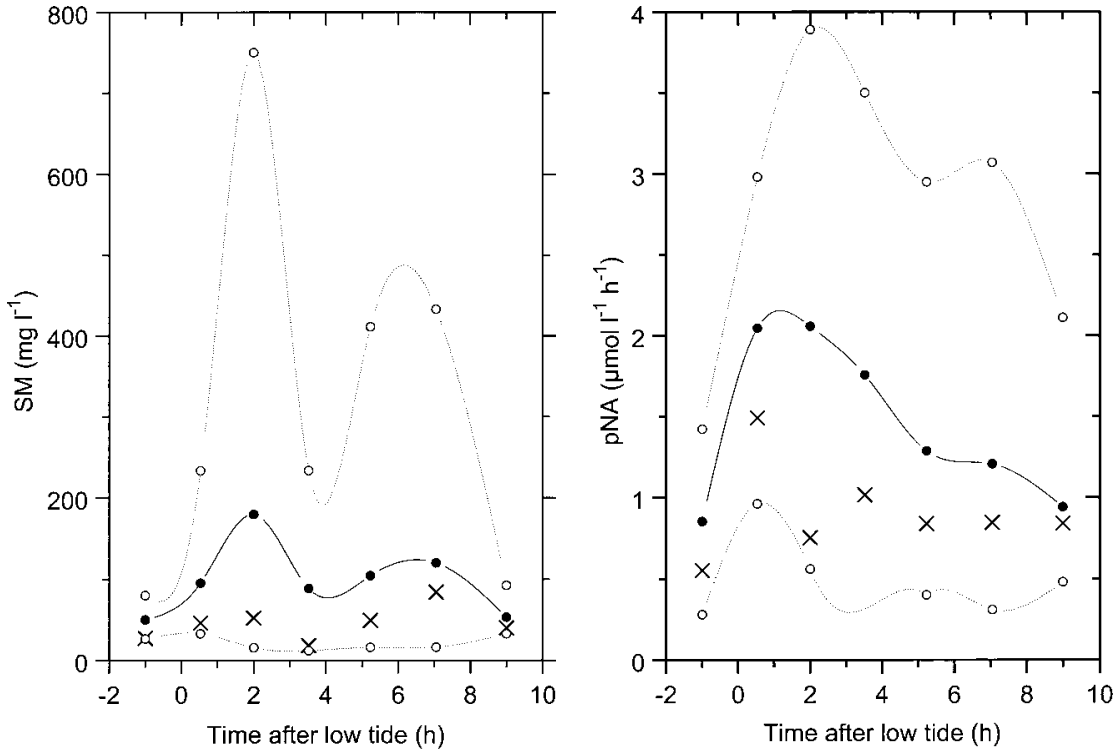

Fig. 8. Variability of the suspended matter (SM) and potential nitrifying activity (pNA) measurements on a cross section at station Moulineaux $(258 \mathrm{~km})$ along a tidal cycle on September 27, 1996. Crosses represent the surface measurements, dotted lines with open circles are the minimum and maximum values on the cross section, and the full line with filled circles is the integrated average value on the cross section.

mum river discharges. SM measurements performed twice monthly by the SNS at $198 \mathrm{~km}$ and at $260 \mathrm{~km}$, from 1990 to 1995 , show that during high discharge periods, SM concentrations in the river are higher than at the estuarine station, while during periods of low discharge, the opposite is observed (Fig. 10). It seems clear that there is an accumulation of particles in the estuary throughout the low water flow period, when the residence time of particles in the estuary is probably longer than the water residence time.

Although our description of the particle dynam-

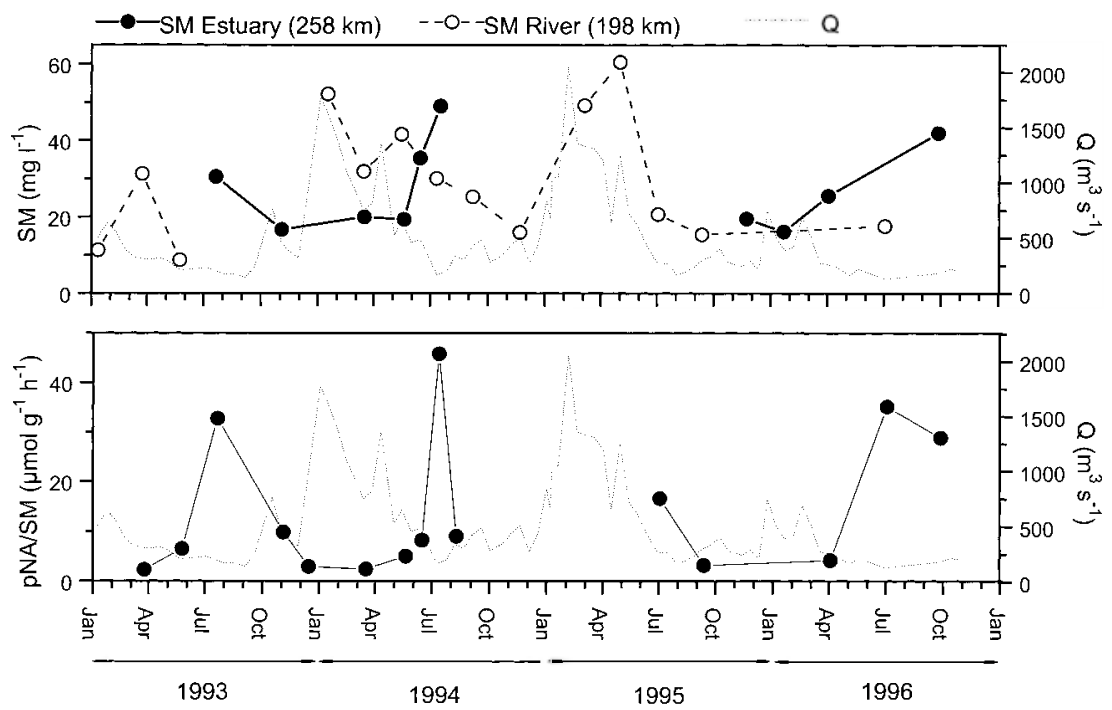

Fig. 9. Seasonal variations of suspended matter concentration (SM) at stations Poses dam (198 km, in the river) and Moulineaux $(258 \mathrm{~km}$, in the estuary), and potential nitrifying activity on these particles (pNA:SM) at station Moulineaux (258 km). Mean surface suspended matter concentration is calculated by integrating the tidal profiles of Figs. 4 and 5. Some supplementary data were given by the Service de la Navigation de la Seine (SNS) pNA:SM. Potential nitrifying activity associated with suspended matter is calculated as the slope of the linear regression during tidal variations of SM and PNA (see Table 1) or as the simple single pNA divided by SM measurements. River discharge is presented as a dotted line. 


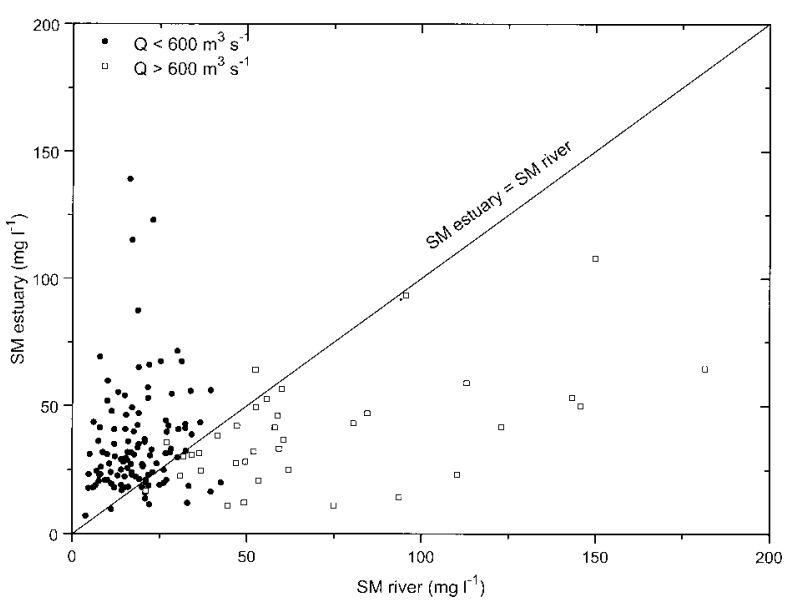

Fig. 10. Suspended matter (SM) measured at Moulineaux $(258 \mathrm{~km}$, in the estuary) versus suspended matter measured at Poses dam (198 km, before the estuary) for 2 discharge categories, between 1990 and 1995. (Service de la Navigation de la Seine unpublished data).

ics in the Seine estuary may be simplistic, a recent detailed hydro-sedimentary study on particle transport in the Seine estuary made by Guézennec et al. (1999) came to the same conclusions. The accumulation of particles in the estuary during summer could have important implications for the growth of the nitrifying population. The slope of the regression lines of potential nitrifying activity versus suspended matter given in Table 1 provides a measure of the nitrifying biomass associated to those particles. Additional data were obtained by dividing single measurements of $\mathrm{pNA}$ made at station Moulineaux $(258 \mathrm{~km})$ with $\mathrm{SM}$, making the simplifying hypothesis that all nitrifying bacteria are associated with all the particles. The seasonal variations of this pNA:SM ratio (Fig. 9) show that particles are progressively colonized by nitrifying bacteria with a very sharp and high peak corresponding to the summer minimum river discharges. This maximum also occurs during peak summer temperatures which are particularly favorable to the growth of nitrifying bacteria, but the sharpness of the peak suggests that the long residence times of the particles to which nitrifying bacteria are attached are favorable to the development of important biomasses. The association of nitrifying bacteria to particles with longer residence times than water masses represents thus a benefit for the development of these slow growing organisms. A physiological study of nitrifying bacteria in the Ems-Dollard estuary by Helder and De Vries (1983) also came to the conclusion that it was only by association with suspended matter accumulating inward by the tides, that the nitrifiers can maintain themselves in the water. In another study made on the small Tamar River estuary, Owens (1986) came to the same conclusions by comparing estuarine nitrification to a fluidized bed reaction.

\section{ACKNOWLEDGMENTS}

This work was supported by the French research programs Programme Interdisciplinaire de Recherche sur l'EnvironnementSeine (Gentre National de Recherche Scientifique, Agence de l'Eau Seine Normandie) and Seine-aval (Région Haute Normandie). At the time of this work Natacha Brion was a doctoral research-fellow of the Fond pour la formation à la Recherche pour l'Industrie et l'Agronomie (Belgium) and Gilles Billen was the research-director of the Fond National de Recherche Scientifique (Belgium)

\section{Literature Cited}

Admiraal, W. And Y. J. H. Botermans. 1989. Comparison of nitrification rates in three branches of the lower river Rhine. Biogeochemistry 8:135-151.

Avoine, J., G. P. Allen, M. Nighols, J. C. Salomon, and G. LARSONNEUR. 1981. Suspended sediment transport in the Seine estuary, France: Effect of man-made modifications on estuary-shelf sedimentation. Marine Geology 40:119-137.

BELSER, L. W. AND E. L. MAYS. 1982. Use of nitrifier activity measurements to estimate the efficiency of viable nitrifiers count in soils and sediments. Applied and Environmental Microbiology 43:945-948.

BEROUNSKY, V. M. AND S. W. NixON. 1993. Rates of nitrification along an estuarine gradient in Narrangaset Bay. Estuaries 16: $718-730$.

BILLEN, G. 1975. Nitrification in the Scheldt estuary (Belgium and The Netherlands). Estuarine and Coastal Marine Science 3: $79-89$.

BoON, B. AND H. LAUdelout. 1962. Kinetics of nitrite oxidation by Nitrobacter Winogradskyi. Biochemical Journal 85:440-477.

Bovendeur, J., A. B. ZwaGa, B. G. J. Lobee, and J. H. Blom. 1990. Fixed-biofilm reactors in aquacultural water recycle systems: Effect of organic matter elimination on nitrification kinetics. Water Research 2:207-213.

BRION, N. AND G. BILLEN. 1998. Une réévaluation de la méthode d'incorporation de $\mathrm{H}^{14} \mathrm{CO}_{3}{ }^{-}$pour mesurer la nitrification autotrophe et son application pour estimer des biomasses de bactéries nitrifiantes. Revue des Sciences de l'Eau 11:283-302.

CASPERS, H. 1981. Seasonal effects on the nitrogen cycle in the freshwater section of the Elbe estuary. Verhandlungen Internationale Vereinigung für Limnologie 21:866-870.

Chestérikoff, A., B. Garban, G. Billen, and M. Poulin. 1992. Inorganic nitrogen dynamics in the river Seine downstream from Paris (France). Biogeochemistry 17:147-164.

COOPER, A. B. 1984. Activities of benthic nitrifiers in streams and their role in oxygen consumption. Microbial Ecology 10 : 316-333.

DÉRI, A. 1991. The role of nitrification in the oxygen depletion of the River Danube. Verhandlungen Internationale Vereinigung für Limnologie 24:1965-1968.

Garnier, J., G. Billen, And M. Coste. 1995. Seasonal succession of diatoms and chlorophycaea in the drainage network of River Seine: Observations and modelling. Limnology and Oceanography 40:750-765.

Gould, G. W. AND H. LeEs. 1960. The isolation and culture of nitrifying organisms. Part 1. Nitrobacter. Canadian Journal of Microbiology 6:299-307.

Grabemann, I., R. J. Ungles, G. Krtause, and J. A. Stephens. 1997. Behaviour of turbidity maxima in the Tamar (U.K.) and Weser (F.R.G.) estuaries. Estuarine, Coastal and Shelf Science 45: 235-246.

Guézennec, L., R. Lafite, J.-P. Dupont, R. Meyer, and D. BousT. 1999. Hydrodynamics of suspended particulate matter 
in the tidal freshwater zone of a macrotidal estuary (the Seine estuary, France). Estuaries 22:717-727.

Helder, W. AND R. T. P. DE VRIES. 1983. Estuarine nitrite maxima and nitrifying bacteria (Ems-Dollard estuary). Netherlands Journal of Sea Research 17:1-18.

JONES, M. N. 1984. Nitrate reduction by shaking with cadmium, alternative to cadmium columns. Water Research 18:643-646.

Lipschultz, F., S. G. Wofsy, AND L. E. Fox. 1986. Nitrogen metabolism of the eutrophic Delaware River ecosystem. Limnology and Oceanography 31:701-716.

Nedwell, D. B., T. D. Jickells, M. Trimmer, and R. Sanders. 1999. Nutrients in estuaries. Advances in Ecological Research 29: 43-92.

OWENs, N. J. P. 1986. Estuarine nitrification: A naturally occurring fluidized bed reaction? Estuarine and Coastal Shelf Science 22:31-44.

SkinNer, F. A. ANd N. Walker. 1961. Growth of Nitrosomonas europaea in batch and contimuous culture. Archives fur Mikrobiologie 38:339-349.

SLAWYC, G. AND J. J. MCISAAC. 1972. Comparison of two automated ammonium methods in a region of coastal upwelling. Deep-Sea Research 4:393-450.

Strahler, A. N. 1957. Quantitative analysis of watershed geomorphology. Transaction, American Geophysical Union 38:913920 .

\section{SOURCE OF UNPublished MATERIAls}

Service de la Navigation de la Seine (SNS). Unpublished data. Service maritime de la Seine-Maritime (3ème Section), Cellule Antipollution de la Seine à Rouen, 66 Av. Jacques Chastellain, 76000 Rouen, France.

Received for consideration, March 23, 1999 Accepted for publication, June 12, 2000 